\title{
Analysis of Student Conformity Based on Gender Using the Rasch Model
}

\author{
Yull Reinita ${ }^{1}$, Mega Iswari' ${ }^{2}$, Febri Wandha Putra ${ }^{3}$ \\ 1,2 Universitas Negeri Padang \\ ${ }^{3}$ Institut Agama Islam Negeri Sumatera Barat \\ *Corresponding author, e-mail: yullreinita1@gmail.com
}

\begin{abstract}
This research is based on the phenomenon that occurs, namely there are still students who differentiate themselves based on the groups they associate with at school, causing some students to get into problems. This type of research is a comparative descriptive which aims to describe the differences in conformity based on the gender of the students. The population in this study were students of SMK class XI. The sampling technique in this research is to use random sampling technique. The instrument used was a Likert scale model and a questionnaire containing statements related to student conformity. Test the validity of the instrument using the Rasch Model. The data analysis technique used the Independent Sample t-Test. The results of the study found that there were differences in conformity between male and female students.
\end{abstract}

Keywords: Gender, Conformity, Student

How to Cite: Reinita, Y., Iswari, M., \& Putra, F.W. (2020). Analysis of Student Conformity Based on Gender Using the Rasch Model. International Journal of Applied Counseling and Social Sciences, 2 (1): pp. 21-26, DOI: https://doi.org/10.24036/005390ijaccs

\section{Introduction}

Psychological adolescence is a transitional period from childhood to adulthood, during adolescence there is cognitive maturity, namely the interaction of perfect brain structures and a wider social environment that allows adolescents to think abstractly (Hurlock, 2003). Initially, teenagers had to quickly adjust to their surroundings such as school and peers. Change by increasing peer group influence, changes in social behavior such as placing more importance on greatness such as using physicality, if what one wants is not achieved or because there is support from friends in groups makes him feel more confident because he feels someone will defend later, new social groupings, new values in social support and resistance. The influence of the strong social environment makes adolescents unable to control themselves (Rahmayanthi, 2017).

In the current industrial revolution era, conformity becomes the support for individuals to interact with others. Conformity is changing actions or behaviors caused by pressure from a particular group or thing (Rapee, Oar, Johnco, Forbes, Fardouly, Magson \& Richardson,, 2019). Conformity is usually carried out by teenage students against peer groups. Adolescents still have emotions that are volatile, so it makes it easy for them to make decisions that go against existing norms in order to accept in certain groups. Conformity occurs when a person changes behavior or attitudes to resemble the behavior or attitudes of a certain group (Cialdini \& Goldstein, 2004). According to Baron \& Byrne (2005) Adolescent 
conformity is the change of adolescent behavior to adhere to reference group norms, accepting group ideas or rules that regulate the way adolescents behave. Someone conforms to a group only because individual behavior is based on the expectations of the group or society.

Conformity is the tendency of individuals to change their perceptions, opinions and behavior so they are under or consistent with group norms (Haser \& Karneli, 2020; Pratiwi \& Karneli, 2020). The great desire to achieve harmony and get social acceptance makes adolescents conform to their peers or groups. According to Jiang, Bong \& Kim (2015), conformity means submitting to the group, even though there is no direct request to follow what the group has done. Friendship is a relationship that is reciprocal, balanced, and stable. The influence of peer groups is very strong on adolescents.

Baron \& Byrne (2005) there are four factors that affect conformity, namely: cohesiveness, group size, social support, gender differences.

Gender (sex) according to Hungu, (2007); Swim, Gillis \& Hamaty (2020) is the difference between a woman and a man biologically since a person is born. Sex is related to the bodies of men and women, where men produce sperm, while women produce eggs and are biologically capable of menstruation, pregnancy and breastfeeding. Biological differences and biological functions of men and women cannot be exchanged between the two, and their function remains with men and women in all races on earth. Fakih (2006) argues that gender is a trait inherent in both men and women that is constructed socially and culturally. Changes in characteristics and characteristics that occur from time to time and from place to place are called the concept of gender.

Men and women have differences in conformity. In situations where there is pressure in the group and there is an audience in it, women are easier to conform than men. Conformity is more common in adolescent girls, this is because young girls are described as gentle, wise, sensitive to the feelings of others, interested in self-appearance, and have a very large need for security (Vantieghem \& Van Houtte, 2015).

Terkait Gender Role, Bem (Bonnita, Sarwono \& Novianti, 2006) mentioned that one of the differentiators of conformity can be seen from gender. Research conducted by Hollander \& Julian ( (Zikmund, Sciglimpaglia, Lundstrom \& Cowell, 1984) shows that there is a greater tendency for women to conform than men.

The phenomenon that occurs shows that there are still indications of negative peer conformity, such as students who skip class when invited by friends, there are also students who smoke during recess because of friends, do not wear complete school attributes because of friends' invitations, lying, spending school fees, stealing parents' money, not having the courage to come to school because they do not bring donations for school education development, and some students skip class together. Some male students were seen in groups with most of them wearing buds, this was because of the influence these students got from their friends who also wore pants with the same model. The phenomenon seen in female students is not much different from the group of male students, where they are also in groups wearing the same clothing model, namely wearing a hanging skirt, wearing short socks in the sense that it is below the ankles and wearing a pointed headscarf. This is because students are accepted into their group and it is their collective decision, and if they don't follow the group rules, they will be ostracized by their group of friends.

The purpose of this study was to test the conformity instruments of students and to describe the differences in conformity between male students and female students.

\section{Method}

This research is a quantitative research with comparative descriptive data analysis which aims to describe the differences in conformity between male students and female students. Sampling in this study using random sampling technique. The sample in this study amounted to 176 students of Vocational High School grade 11, consisting of 49 male students and 127 female students. The type of 
instrument used is a Likert scale model and a questionnaire containing statements about conformity developed from the theory Baron \& Byrne (2005). Test the validity of the instrument using statistical fit analysis through the Rasch Model application (Alagumalai, Curtis \& Hungi, 2005; Bond, Yan \& Heene, 2020; Sumintono \& Widhiarso, 2015). Furthermore, to see the results of different tests, an analysis was carried out using the Independent Sample t Test formula.

\section{Results and Discussion}

\section{Conformity Instrument Quality Test}

Table 1 shows that the item reliability value is 0.99 . This means that the quality of the instrument items used to measure students' conformity is at a special level. In addition, the reliability value of the score based on Cronbach's Alpha (KR-20) is 0.72, which means that the interaction between respondents and items is good. The value of separation indexs of items is 8.73. This shows that the quality of the instrument in terms of overall respondents and items is good. In addition, the response sensitivity pattern value + 1.03 logit (INFIT MNSQ Item) and the overall person response pattern sensitivity value +1.03 logit (OUTFIT MNSQ) show that they are in the ideal range $(+0.5<\mathrm{MNSQ}>+1.5)$. This means that the instrument has a very good quality to be used to measure student conformity.

Table 1. Result of Quality Test of Conformity Instruments

\begin{tabular}{lc}
\hline \multicolumn{1}{c}{ Estimation } & Values \\
\hline Item Reliability & 0.99 \\
Cronbach Alpha (KR-20) & 0.72 \\
Separation indexs of Item & 8.73 \\
Mean OUTFIT MNSQ Item & 1.02 \\
Mean INFIT MNSQ Item & 1.03 \\
Raw variance explained by measures & $41.5 \%$ \\
\hline
\end{tabular}

To see the difference in conformity between male students and female students, data analysis was carried out using the T-test. The results can be seen in the table below.

Table 2. Analysis of Independent sample t-test Peer Conformity in terms of Gender

\begin{tabular}{ccccc}
\hline Values & \multicolumn{2}{c}{ Lavane test } & \multicolumn{2}{c}{ T-test } \\
\hline Student Conformity & F & Sig. & Sig. (2 tailed) & $\mathrm{t}$ \\
\cline { 2 - 5 } & 1.003 & .318 & .030 & 2.132 \\
\hline
\end{tabular}

The results of the above analysis show that the $t$ test value (sig. $(2$ tailed $)=.030)$, it can be interpreted that the $p$-value is $<0.05$, which shows that there is a difference in conformity between male students and female students. In addition, the difference in peer conformity between male students and female students can also be seen through the Lavane test results (Sig. $=.318)>0.05$, so there are differences in conformity between male students and female students. In line with this research, Istiana \& Ainun (2018) states that the conformity of male students differs from the conformity of female students, which is the conformity of male students (66.2) and the conformity of female students (111.66). The results of other study also show that there are differences in conformity between men and women (Eagly \& Chrvala, 1986; Wijenayake, Berkel, Kostakos \& Goncalves, 2019). The difference in conformity itself occurs because there are informational and normative influences (Carter, Franz, Gruschow \& VanRyne, 2019; Skinner, Kutz-Costez, Wood \& Rowley, 2018). 


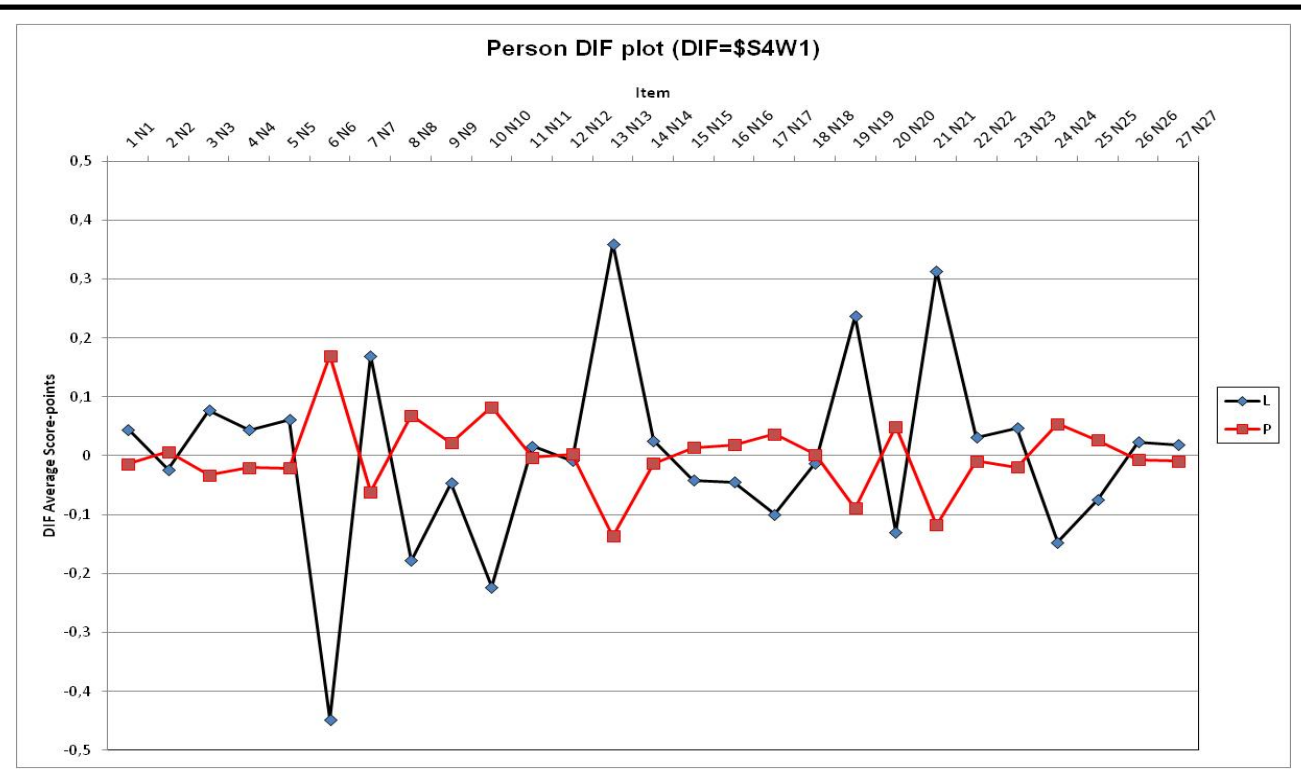

Figure 1. Differences in Student Conformity in terms of Gender

In Figure 1, it can be seen that the male students' conformity is higher than that of female students. This can be seen from the ability of male students to respond to the instrument is higher than the response of female students. This is supported by Cooper (1979) through the results of his research which found that male conformity was higher than female, with high conformity making it easier for men to adapt to social environments. Furthermore, Cross, Brown, Morgan \& Laland (2017) mentioned that high conformity makes men more comfortable socializing than women. This result contradicts the results of the research Istiana \& Ainun (2018) which states that the conformity of male students is lower than the conformity of female students. The results of other research also state that the tendency for female students to conform is higher than that of male students (Kristina, Elvinawaty \& Mailani, 2013). Other than that, Eagly, Wood \& Fishbaugh (1981) states that women's conformity is higher than women's, this happens when their opinions are under the supervision of others. Besides, according to Sarwono \& Meinarno (2009), women conform more easily than men and there are two causes, namely: women's personality is more flexible, and women's status is more limited so they do not have many options, except to adjust to the situation. This stereotype is subconsciously attached to teenage girls. They are often seduced by other people, in this case their group of friends, from general things such as clothing styles.

\section{Conclusion}

Based on the explanation above, the conclusions of this study show that the quality of the conformity instrument is very good to be used to measure the conformity of students, both those with high conformity and low conformity. Apart from this, the results of the study also found that there were differences in conformity between male students and female students, where the male students' conformity was higher than female students. This can be seen from several aspects that show male students who are easier to adjust with high conformity than female students who have low conformity. However, that does not mean that female students are unable to adjust to low conformity. The results of the research can be a suggestion for counselors to provide Counseling Guidance services that are evenly distributed to students. The limitations of this study can be seen from the number of samples with male types less than female students.

\section{References}

Alagumalai, S., Curtis, D. D., \& Hungi, N. (2005). Applied Rasch measurement: A book of exemplars. Netherlands: Springer.

Baron, R. A., \& Byrne, D. (2005). Psikologi sosial. Jakarta: Erlangga. 
Bond, T., Yan, Z., \& Heene, M. (2020). Applying the Rasch model: Fundamental measurement in the human sciences. Routledge.

Bonnita, A., Sarwono, S. W., \& Novianti, A. (2006). Sumbangan Prasangka Gender Pada Sikap Bawahan Terhadap Manajer Perempuan. Jurnal Psikologi Sosial, 12(3), 169-180.

Carter, M. F., Franz, T. M., Gruschow, J. L., \& VanRyne, A. M. (2019). The gender conformity conundrum: The effects of irrelevant gender norms on public conformity. Journal of Social Psychology, 159(6), 761-765. https://doi.org/10.1080/00224545.2019.1586636

Cialdini, R. B., \& Goldstein, N. J. (2004). Social influence: Compliance and conformity. Annual Review of Psychology, 55(1974), 591-621. https://doi.org/10.1146/annurev.psych.55.090902.142015

Cooper, H. M. (1979). Statistically combining independent studies: A meta-analysis of sex differences in conformity research. Journal of Personality and Social Psychology, 37(1), 131-146. https://doi.org/10.1037/0022-3514.37.1.131

Cross, C. P., Brown, G. R., Morgan, T. J. H., \& Laland, K. N. (2017). Sex differences in confidence influence patterns of conformity. British Journal of Psychology, 108(4), 655-667.

Eagly, A. H., \& Chrvala, C. (1986). Sex differences in conformity: Status and gender role interpretations. Psychology of Women Quarterly, 10(3), 203-220. https://doi.org/10.1111/j.1471-6402.1986.tb00747.x

Eagly, A. H., Wood, W., \& Fishbaugh, L. (1981). Sex differences in conformity: Surveillance by the group as a determinant of male nonconformity. Journal of Personality and Social Psychology, 40(2), 384394. https://doi.org/10.1037/0022-3514.40.2.384

Fakih, M. (2006). Analisis gender \& transformasi sosial. Yogyakarta: Pustaka Pelajar.

Haser, R., \& Karneli, Y. (2020). Differences in Student Aggressive Behavior Judging from Peer Conformity and Its Implications in Counseling Guidance Services. Jurnal Neo Konseling, 2(3), 110. https://doi.org/10.24036/00287kons2020

Hungu. (2007). Demografi Kesehatan Indonesia. Jakarta: Grasindo.

Hurlock, E. B. (2003). Psikologi perkembangan anak dan remaja. In Jakarta: Erlangga. Jakarta: Erlangga.

Istiana, I., \& Ainun, N. (2018). Perbedaan Konformitas Ditinjau dari Jenis Kelamin Pada Remaja di Sekolah Madrasah Tsanawiyah Irsyadul Islamiyah Kecamatan Bagan Sinembah. Psikologi Prima, 1(2), 34-45.

Jiang, Y., Bong, M., \& Kim, S. il. (2015). Conformity of Korean adolescents in their perceptions of social relationships and academic motivation. Learning and Individual Differences, 40, 41-54. https://doi.org/10.1016/j.lindif.2015.04.012

Kristina, M., Elvinawaty, R., \& Mailani, L. (2013). Gender Diffrences in the Tendency To Conform Among SMA Raksana Medan Students. Psikologia, 8(1), 12-18.

Pratiwi, R., \& Karneli, Y. (2020). The Contribution of Online Gaming and Peer Conformity to Student Bullying Behavior. Jurnal Aplikasi IPTEK Indonesia, 4(3), 155-161. https://doi.org/10.24036/4.34375

Rahmayanthi, R. (2017). Konformitas Teman Sebaya dalam Perspektif Multikultural. JOMSIGN: Journal of Multicultural Studies in Guidance and Counseling, 1(1), 71-82. https://doi.org/10.17509/jomsign.v1i1.6052

Rapee, R. M., Oar, E. L., Johnco, C. J., Forbes, M. K., Fardouly, J., Magson, N. R., \& Richardson, C. E. (2019). Adolescent development and risk for the onset of social-emotional disorders: A review and conceptual model. Behaviour Research and Therapy, 123, 103501.

Sarwono, S. W., \& Meinarno, E. A. (2009). Psikologi sosial. In Jakarta: Salemba Humanika.

Skinner, O. D., Kurtz-Costes, B., Wood, D., \& Rowley, S. J. (2018). Gender Typicality, Felt Pressure for Gender Conformity, Racial Centrality, and Self-Esteem in African American Adolescents. 


\section{Journal of Black Psychology, 44(3), 195-218. https://doi.org/10.1177/0095798418764244}

Sumintono, B., \& Widhiarso, W. (2015). Aplikasi Pemodelan Rasch pada Assessment Pendidikan. Trim Komunikata.

Swim, J. K., Gillis, A. J., \& Hamaty, K. J. (2020). Gender Bending and Gender Conformity: The Social Consequences of Engaging in Feminine and Masculine Pro-Environmental Behaviors. Sex Roles, 82(5-6), 363-385. https://doi.org/10.1007/s11199-019-01061-9

Vantieghem, W., \& Van Houtte, M. (2015). Are Girls more Resilient to Gender-Conformity Pressure? The Association Between Gender-Conformity Pressure and Academic Self-Efficacy. Sex Roles, 73(1-2), 1-15. https://doi.org/10.1007/s11199-015-0509-6

Wijenayake, S., Van Berkel, N., Kostakos, V., \& Goncalves, J. (2019). Measuring the effects of gender on online social conformity. Proceedings of the ACM on Human-Computer Interaction, 3(CSCW), 1-24. https://doi.org/10.1145/3359247

Zikmund, W. G., Sciglimpaglia, D., Lundstrom, W. J., \& Cowell, R. G. (1984). The Effects of Gender and Product Stereotyping on Conformity Judgements: an Experiment. ACR North American Advances. 